\title{
CELULARES, CONEXÕES E AFETOS: A SOCIABILIDADE E O CONSUMO DE SMARTPHONES POR JOVENS DE CO- MUNIDADE POPULAR
}

\author{
SANDRA RUBIA DA SILVA \\ UNIVERSIDADE FEDERAL DE SANTA MARIA \\ SANTA MARIA, RIO GRANDE DO SUL, BRASIL \\ SANDRAXRUBIA@GMAIL.COM \\ ROMULO TONDO \\ UNIVERSIDADE FEDERAL DE SANTA MARIA \\ SANTA MARIA, RIO GRANDE DO SUL, BRASIL \\ ROMULOTONDO@GMAIL.COM
}

HTTP://DX.DOI.ORG/10.5902/2316882X23967 
CELULARES, CONEXÕES E AFETOS: A SOCIABILIDADE E O CONSUMO DE SMARTPHONES POR JOVENS DE COMUNIDADE POPULAR

Resumo: A investigação em questão reflete o consumo dos smartphones por jovens de comunidade popular de Santa Maria a partir de uma pesquisa etnográfica. A posse, os usos e as apropriações dos telefones celulares por estes sujeitos potencializa a manutenção e a construção das redes de afinidade, especialmente para a circulação de dados de caráter afetivo. Palavras-chave: Consumo; Juventude; Smartphones

\section{CELULARES, CONEXIONES Y AFECTOS: LA SOCIABILIDAD Y EL CONSUMO DE SMARTPHONES ENTRE LOS JÓVENES DE COMUNI- DAD POPULAR}

Resumen: La investigación en cuestión refleja el consumo de smartphones por jovenes de una comunidad popular Santa Maria a partir de una investigación etnográfica. Posesión, los usos y apropiaciones de los teléfonos móviles por parte de estos sujetos mejora el mantenimiento y construcción de redes de afinidad, especialmente para el movimiento de datos de carácter afectivo.

Palabras clave: Consumo; Juventud; Smartphones

\section{CELL PHONES, CONNECTIONS AND AFFECTS: THE SOCIABILITY AND THE CONSUMPTION OF SMARTPHONES BETWEEN YOUNGER IN POPULAR COMMUNITY}

Abstract: The research in question reflects the consumption of smartphones by youth from popular community an ethnographic research in Santa Maria. The possession, the uses and appropriations of mobile phones by these subjects enhances the maintenance and construction of affinity networks, especially for the movement of affective character data.

Keywords: Consumption; Youth; Smartphones 


\section{CONSIDERAÇÕES INICIAIS}

Durante décadas o consumo foi observado como um processo social obscuro, capaz de provocar a degradação da humanidade (MILLER, 2007). No entanto, com o desenvolvimento dos estudos no campo da Antropologia do consumo foi possível compreender que as demandas de posse e apropriação dos objetos são integrantes de um processo sociocultural permeado por construções individuais e coletivas. Neste estudo, o consumo é compreendido como um exercício de comunicação no qual os jovens ${ }^{1}$ participantes relatam os usos e as apropriações do smartphone em suas experiências cotidianas com e através dessa mídia. Logo, é possível pensar como Daniel Miller (2013) que a utilização e a construção cultural dos objetos estão atravessadas pelas necessidades do sujeito e da simbologia que o mesmo possui na sociedade na qual está inserido. Em tal perspectiva, a posse, os usos e as apropriações dos smartphones pelos jovens torna-se fértil para um estudo qualitativo. Portanto, a dissertação situa-se na interface entre a Comunicação e a Antropologia Social, utilizando-se da etnografia como construção de um estudo teórico-metodológico, calcado na observação participante e na interpretação dos dados obtidos através do convívio e das entrevistas semiestruturadas junto aos jovens da comunidade do Jardim Aurora².

Diante disso, esta pesquisa vem somar esforços com uma série de investigações brasileiras que versam seus olhares sobre o consumo das camadas populares (BARROS, 2007; ROCHA, 2009; SILVA, 2010; PINHEIRO MACHADO e SCALCO, 2012, PAVESI, 2014, YACOOUB, 2015, entre outros).

$1 \quad$ Na atualidade, a juventude pode ser compreendida para além da categoria etária, e sim, como uma construção social decorrente das amarrações sociais de um determinado povo. Na perspectiva de Canclini (2015) o sentido da juventude está atrelada ao "sentido intercultural do tempo". Por esse ângulo, a juventude apresenta características para além de uma determinação etária, englobando as necessidades de uma sociedade em constante transformação.

2 Os nomes adotados nesta investigação são pseudônimos para proteger a identidade dos jovens envolvidos na pesquisa. Fonseca (2010) argumenta que o uso do anonimato deve ser estudado com cautela pelo investigador e seus interlocutores. Segundo a autora, existem algumas pesquisas que a utilização dos nomes dos interlocutores e da própria causa podem auxiliar na mobilização e na construção de novas demandas sociais.

Rev.Cad.Comun. Santa Maria, v.21, n.2, art 7, p. 141 de 147, maio/ago.2017 
Este estudo visa ainda, especialmente, contribuir com as pesquisas que constroem um olhar sobre o consumo tecnológico tomando como objeto empírico os telefones celulares. A partir da vivência e observação do cotidiano desses jovens acreditamos que os celulares se tornam dispositivos essenciais para a construção da sociabilidade e (re)mediação dos afetos entre os jovens e suas redes de afinidade na sociedade moderno-contemporânea.

\section{A ETNOGRAFIA: OBSERVAR, AFETAR E CONSUMIR DADOS MÓ- VEIS}

Uma das principais funções de uma pesquisa científica é fazer avançar a compreensão sobre determinado campo e oferecer, de certa forma, uma compreensão analítica sobre um tema abordado e problematizado a partir de uma questão norteadora. Na construção da dissertação optou-se pela pesquisa etnográfica. Considerado o principal método utilizado pelos antropólogos, e apropriada por diferentes Ciências que buscam, a partir da pesquisa qualitativa, observar, compreender e apresentar descritivamente as lógicas de um determinado grupo social.

A partir das experiências observadas e relatadas pelos interlocutores da pesquisa, chamados de nativos, é possível desenvolver uma compreensão sobre as suas próprias lógicas de construções socioculturais. Nesta investigação, o cerne da pesquisa etnográfica foi ancorada nas ideias dos antropólogos Roberto Cardoso de Oliveira (2006) e Clifford Geertz (2008). Cardoso de Oliveira (2008) nos apresenta que a construção da pesquisa etnográfica é permeada pelo "olhar, ouvir e escrever". Os dois primeiros são realizados durante a experiência da vivência do pesquisador no campo; já o terceiro é realizado com o afastamento do investigador do ambiente da pesquisa, neste caso da comunidade do Jardim Aurora, para uma reflexão e estruturação do texto descritivo/ reflexivo. Já para Geertz (2008) a etnografia é atravessada pela construção e reflexão a partir da interpretação dos dados, criando-se uma "teia de significados" que serão responsáveis pelo encadeamento da "descrição densa" das relações e práticas socioculturais desenvolvidas pelos sujeitos.

Sendo assim, em linhas gerais, as atividades de campo da investigação deram-se em dois momentos, perdurando 17 meses: a aproximação dos jovens da comunidade, realizada entre os meses de março e dezembro

Rev.Cad.Comun. Santa Maria, v.21, n.2, art 7, p. 142 de 147, maio/ago. 2017 
de 2014, com educandos do ensino médio e professores da Escola Anita Garibaldi; e a imersão, realizada entre os meses de janeiro e setembro de 2015, com quatro jovens moradores da comunidade do Jardim Aurora e suas famílias.

Durante a aproximação com os jovens foi proposta uma oficina educomunicativa na Escola Anita Garibaldi. A atividade tinha como finalidade observar o uso do celular e consequentemente a utilização do objeto como instrumento de auxiliasse no protagonismo juvenil dos estudantes, acolhido através de uma oficina de fotografia e mostrando o olhar desses sujeitos a essência da vida na comunidade (TONDO; SILVA, 2015). Já a segunda etapa, a imersão, contou com a observação e convívio com quatro jovens com idades entre 15 e 21 anos, de ambos os sexos biológicos, três meninas e um menino.

Nesta investigação, o artefato foi apropriado pelos jovens como o principal dispositivo de conexão com seus pares e seus familiares: o telefone celular está no núcleo das experiências juvenis e dá suporte à fragmentação (ROCHA; PEREIRA, 2009) e à construção de estratégias de consumo que fazem do smartphone um coordenador das atividades (LING, 2001).

O smartphone é utilizado por esses jovens diferentes momentos do cotidiano, sendo capaz de substituir diferentes objetos na vida dos participantes da pesquisa, revolucionando a maneira com que esses sujeitos se relacionam com outros objetos e como consomem outras mídias. A partir dos usos cotidianos do dispositivo, os dados são pensados a partir do conceito de "fragmentação" (ROCHA; PEREIRA, 2009) e "tecnologia afetiva" (LASÉN, 2004).

O olhar sobre compreensão da fragmentação em Rocha e Pereira (2009) nos interessa suscitar a construção a partir da fragmentação dos saberes, da cultura pós-moderna e da facilidade dos jovens em circular em diferentes ambientes. Já a tecnologia afetiva (LASÉN, 2004) por meio dos dados que circulam e afetam os sujeitos a partir dos usos e apropriações de celulares em seus cotidianos. Posto isto, as categorias trabalhadas na dissertação foram: o amor, a relação entre mães e filhos através do consumo do dispositivo; a violência, a partir do furto do telefone celular de um dos interlocutores e também da circulação de imagens intimas em um grupo de Whatsapp; e por último, a materialidade (MILLER, 2013) da relação entre os celulares e smartphones no uso de jovens e adultos.

Rev.Cad.Comun. Santa Maria, v.21, n.2, art 7, p. 143 de 147, maio/ago.2017 
Como forma de elucidar a categoria amor é apresentado a seguir um fragmento sobre o uso cotidiano do celular por Laura. A jovem possui 21 anos, é mãe de Davi que possui um ano, mora com os seus pais e busca qualificação profissional para inserção no mercado de trabalho. Com o processo de construção do campo, Laura tornou-se a principal interlocutora da pesquisa. Ganhou seu primeiro celular na adolescência e utilizava o dispositivo para jogar e tirar fotos. Na atualidade, ela utiliza com destreza as redes sociais, especialmente o Facebook e Whatsapp, faz download de jogos, músicas e aplicativos para passar o tempo. Para além do uso pessoal, utiliza o smartphone para entreter Davi com vídeos do Youtube.

Sempre coloco música logo de manhã cedo para escutar. Geralmente, já acordo com o celular do meu lado. Tomo banho e escuto música, escovo os dentes e escuto música... é bem assim, pela manhã sempre estou escutando música e fazendo algo. Quando o Davi não está parando quieto, tá birrento, pego o celular e mostro para ele, parece que ele é treinado, já dá risada. Parece que vou tirar foto. Daí, coloco ele sentado e dou o celular para ele ou coloco em algum vídeo da galinha pintadinha no YouTube. Já não aguento mais essa músicas da galinha pintadinha, sei todas de cor! Agora também baixei um app que ele já sabe tocar e escutar as musiquinhas. Já deixo na tela principal para ele logo que pegar o celular já ver, né. [E qual aplicativo é esse?] Descobri pela TV e baixei, um do Jacarelvis, que fica cantando música. Bem divertido e faz com que ele fique quieto e prestando atenção. (Laura, 21 anos)

Através desta fala, é possível observar que o telefone celular permeia longas horas do cotidiano da jovem. Do uso individual à elaboração das construções de sociabilidade afetiva com o filho. O smartphone ganha características de artefato de entretenimento, ao mesmo tempo em que é um instrumento de mediação entre a jovem e o filho favorecendo dessa forma a construção de diálogo e apropriação da ferramenta no cotidiano materno. Desta forma, o celular é usado de forma fragmentada e ao mesmo tempo como instrumento a auxiliar na troca de afetos com o filho.

\section{CONSIDERAÇÕES FINAIS}

Na trajetória desta investigação a experiência de campo foi fundamental para construção e obtenção dos dados para uma pesquisa qualitativa voltada para compreensão do consumo de smartphones por jovens de co-

Rev.Cad.Comun. Santa Maria, v.21, n.2, art 7, p. 144 de 147, maio/ago.2017 
munidade popular. A interface entre as Ciências da Comunicação e a Antropologia Social forneceu subsídios para compreender como ocorrem os usos e apropriações do telefone celular no cotidiano de jovens de um bairro popular de Santa Maria.

Nesta perspectiva, Miller (2013) argumenta que os objetos que nos cercam trazem indícios de quem somos. Sob esse ponto de vista, o smartphone proporciona aos jovens numerosas ações que podem impulsionar sua sociabilidade, tornando-se algo complexo e múltiplo. A partir desta observação, acrescento que as memórias afetivas não estão atreladas somente ao consumo fragmentado (ROCHA; PEREIRA, 2009) e às experiências móveis de juvenis. Elas estão também elencadas aos demais consumidores da tecnologia móvel, apesar de serem mais perceptíveis as experiências de consumo oportunizadas pela juventude, diante de um dispositivo hibrido e suas múltiplas conexões (LEMOS, 2007).

Sendo assim, através da experiência de campo foi possível averiguar que entre os jovens do Jardim Aurora o smartphone torna-se um objeto capaz de auxiliar na construção das relações, suscetível a diferentes apropriações e interpretações decorrentes dos usos cotidianos. Sendo assim, é possível ponderar através da construção do aporte teórico que os celulares são capazes potencializar as experiências de vida pela mediação das conexões, responsáveis por construir uma manutenção dos laços sociais com os sujeitos (HORST E MILLER, 2006), bem como mediar os afetos a partir do dispositivo (LASÉN, 2004). Ao mesmo tempo se fazem necessárias novas investigações para compreensão dos usos de aplicativos de redes sociais, como seus usos são responsáveis por construir novas dinâmicas de sociabilidade e construções de afetos a partir de uma tecnicidade e dinâmicas de cada rede social. 
CADERNOS DE COMUNICAÇÃO

UNIVERSIDADE FEDERAL DE SANTA MARIA

\section{REFERÊNCIAS}

BRASIL. Ministério do Planejamento, Orçamento e Gestão. Instituto Brasileiro de Geografia e Estatística. Pesquisa Nacional por Amostra de Domicílios: Acesso à Internet e Posse de Telefone Móvel Celular para Uso Pessoal 2014. Rio de Janeiro: IBGE, 2016.

CANCLINI, Néstor García. Ser diferente é desconectar-se? Sobre culturas juvenis IN: . Diferentes, desiguais e desconectados: mapas da interculturalidade. Tradução:

Luiz Sérgio Henriques. $3^{\mathrm{a}}$ ed. Rio de Janeiro: UFRJ, 2015. pp.209-224.

CARDOSO DE OLIVEIRA, Roberto. O trabalho do antropólogo: olhar, ouvir, escrever. IN: $17-36$. . O trabalho do antropólogo. 2 ed. Brasília: Paralelo; São Paulo: Unesp, 2006. pp.

FONSECA, Claudia. O anonimato e o texto antropológico: dilemas éticos e políticos da etnografia 'em casa'. IN: SCHUCH, Patrice; VIEIRA, Miriam Steffen; e PETERS, Roberta (orgs). Experiências, dilemas e desafios do fazer etnográfico contemporâneo. Porto Alegre: Ed. da UFRGS, 2010. pp. 205-227

GEERTZ, Clifford. A interpretação das culturas. $1^{\text {a }}$ ed. 13. reimpressão. Rio de Janeiro: LTC, 2008.

HORST, Heather; MILLER, Daniel. The Cell Phone: an anthropology of communication. Oxford: Berg, 2006.

LASÉN, Amparo. Affective Technologies: emotions and mobile phones. Surrey: The Digital World Research Centre, 2004. Disponível em: < http://goo.gl/xJyzbO> 22. jun. 2016.

LEMOS, André. Comunicação e práticas sociais no espaço urbano: as características dos Dispositivos Híbridos Móveis de Conexão Multirredes (DHMCM). Comunicação, Mídia e Consumo. São Paulo, Escola Superior de Propaganda e Marketing, vol. 4, nº 10, 2007.

MILLER, Daniel. Trecos, troços e coisas: estudos antropológicos sobre a cultura material. Tradução: Renato Aguiar. Rio de Janeiro: Zahar, 2013.

. Consumo como cultura material. Horizontes Antropológicos, Porto Alegre, ano 13, n. 28, p. 33-63, jul./dez. 2007

PAVESI, Patrícia. Oi, tem internet? Claro! No mundo Tim! Sem conexões não vivo: o consumo do acesso à internet na Grande Terra Vermelha. Tese (Doutorado em Antropologia) Universidade Federal Fluminense, Rio de Janeiro, 2014.

ROCHA, Everado; PEREIRA, Cláudia. Juventude e Consumo: um estudo sobre a comunicação na cultura contemporânea. Rio de Janeiro: Mauad X, 2009.

Rev.Cad.Comun. Santa Maria, v.21, n.2, art 7, p. 146 de 147, maio/ago.2017 
ROCHA, Everardo. Invisibilidade e revelação: camadas populares, cultura e práticas de consumo. IN: ROCHA, Angela; SILVA, Jorge Ferreira. (ORG). Consumo na Base da Pirâmide: Estudos Brasileiros, Rio de Janeiro: Mauad, 2009, pp. 13-19.

SILVA, Sandra Rubia. Estar no tempo, estar no mundo: a vida social dos telefones celulares em um grupo popular. Tese (Doutorado em Antropologia Social), Universidade Federal de Santa Catarina, Florianópolis, 2010.

TONDO, Romulo; SILVA, Sandra Rubia. Celular, imagem e emoção: o consumo e apropriação de telefones celulares na construção do olhar do jovem sobre sua comunidade. In: YACCOUB, Hilaine (Org.). Consumo Popular.1 ed. Rio de Janeiro: Mundo do Marketing Editora. 2015a.pp. 181-200.

YACCOUB, Hilaine. Consumo Popular.1 ed. Rio de Janeiro: Mundo do Marketing Editora. 2015 .

\section{Romulo Tondo}

Mestre em Comunicação (UFSM/2016). Graduado em Comunicação Social (UFSM/2012) e Especialista em Políticas e Intervenção em Violência Intrafamiliar (Unipampa/2014). E-mail: romulotondo@gmail.com

\section{Sandra Rubia da Silva}

Doutora em Antropologia Social pela Universidade Federal de Santa Catarina. Mestre em Comunicação e Informação pela Universidade Federal do Rio Grande do Sul. Docente do Departamento de Ciências da Comunicação e do Programa de Pós-Graduação em Comunicação da Universidade Federal de Santa Maria.

E-mail: sandraxrubia@gmail.com

A dissertação que originou este artigo foi orientada pela professora Sandra Rúbia da Silva e defendida em 21/03/2016, na linha "Mídias e Estratégias Comunicacionais" do POSCOM-UFSM.

RECEBIDO EM: $14 / 09 / 2016$

ACEITO EM: 13/11/2016

Rev.Cad.Comun. Santa Maria, v.21, n.2, art 7, p. 147 de 147, maio/ago.2017 